Jurnal Basicedu Volume 1 Nomor 1 Tahun 2019 Halaman 1- 8

EDUKATIF: JURNAL ILMU PENDIDIKAN

Research \& Learning in Education

https://edukatif.org/index.php/edukatif/index

\title{
PENERAPAN METODE MIND MAPPING UNTUK MENINGKATKAN KEMAMPUAN BERPIKIR KREATIF SISWA SEKOLAH DASAR
}

\author{
Rizki Ananda ${ }^{1}$ \\ Universitas Pahlawan Tuanku Tambusaii ${ }^{1}$ \\ e-mail : rizkiananda.mhs.upi@gmail.com
}

\begin{abstract}
Abstrak
Penelitian ini dilatarbelakangi oleh rendahnya hasil belajar siswa dalam pembelajaran sosial, pembelajaran IPS yang dilakukan cenderung membosankan, dan orientasi pada kemampuan guru untuk hanya mengajarkan pengetahuan yang tidak pada kemampuan analisis, sintesis, dan kreatif. Berdasarkan latar belakang ini, penelitian ini bertujuan untuk meningkatkan kemampuan berpikir kreatif siswa dalam studi sosial. Penelitian ini dilakukan pada siswa kelas V di SDN 018 LangginiBangkinang Kota. Solusinya mengukur penerapan metode yang digunakan adalah Mind Mapping. Berdasarkan hasil survei terungkap bahwa penggunaan metode Mind Mapping dapat meningkatkan kemampuan berpikir kreatif di kelas V SDN 018 LangginiBangkinang Kota. Persentase pencapaian dari proses pembelajaran penerapan siklus pertama adalah $81 \%$, sedangkan pada siklus kedua meningkat menjadi $100 \%$. Nilai rata-rata siswa pretest pada siklus pertama adalah 52 hingga 25\% siswa dalam kategori GOOD, dan siklus kedua meningkat menjadi 78 dengan $70 \%$ siswa dalam kategori GOOD, sedangkan nilai rata-rata hasil post-test dari siswa pada siklus pertama adalah 56 hingga $35 \%$ siswa dalam kategori BAIK, dan siklus kedua meningkat menjadi 80 dengan 80\% siswa dalam kategori BAIK.
\end{abstract}

Kata Kunci: mind mapping, kemampuan berpikir kreatif

\begin{abstract}
This study was motivated by the low student learning outcomes in social studies, learning social studies carried out tend to be boring, and orientation on the ability of teachers to teach only rote knowledge that are not on the ability of analysis, synthesis, and creative. Based on this background, the research aimed to improve the ability of creative thinking of students in social studies. This study was conducted to fifth grade students at SDN 018 LangginiBangkinang Kota. The solution measures the application of the method used is Mind Mapping. Based on the survey results revealed that the use of Mind Mapping method can improve the ability to think creatively in class V SDN 018 LangginiBangkinang Kota. The percentage achievement of the learning process of the implementation of the first cycle is $81 \%$, while in the second cycle increased to $100 \%$. The average value of pretest students in the first cycle is 52 to $25 \%$ of students in the category Good, and the second cycle increased to 78 with $70 \%$ of students in the category Good, while the average value of the post-test results of students in the first cycle is 56 to $35 \%$ of students in the category Good, and the second cycle increased to 80 with $80 \%$ of students in the category Good.
\end{abstract}

Keywords: mind mapping, creative ability

@Edukasi: Jurnal Ilmu Pendidikan FIP UPTT 2019

$\triangle$ Corresponding author :

Address : Bangkinang

Email : rizkiananda.mhs.upi@gmail.com

ISSN xxxx-Xxxx (Media Cetak)

Phone : -

ISSN $\mathrm{xxxx}-\mathrm{xxxx}$ (Media Online) 
2 | Penerapan metode mind mapping untuk meningkatkan kemampuan berpikir kreatif siswa sekolah dasarRizki Ananda

\section{PENDAHULUAN}

Menurut Martorella (Solihatin, 2005:4) "pembelajaran Ilmu Pengetahuan Sosial (IPS) lebih menekankan pada aspek "Pendidikan" daripada "Transfer Konsep", karena dalam pembelajaran pendidikan IPS diharapkan memperoleh pemahaman terhadap sejumlah konsep dan mengembangkannya serta melatih sikap, nilai, moral dan keterampilannya berdasarkan konsep yang telah dimilikinya".

Berkaitan dengan hal tersebut, dalam BSNP (2006:575) dijelaskan bahwa mata pelajaran IPS bertujuan agar peserta didik memiliki kemampuan sebagai berikut: 1) Mengenal konsepkonsep yang berkaitan dengan kehidupan masyarakat dan lingkungannya. 2) Memiliki kemampuan dasar untuk berfikir kreatif,logis serta kritis, rasa ingin tahu, inkuiri, memecahkan masalah, dan keterampilan dalam kehidupan sosial. 3) Memiliki komitmen dan kesadaran terhadap nilai-nilai sosial dan kemanusiaan. 4) Memiliki kemampuan berkomunikasi, bekerjasama dan berkompetensi dalam masyarakat yang majemuk, di tingkat lokal, nasional, dan global.

Dilihat dari tujuan pembelajaran IPS di atas, kemampuan berpikir kreatif dan pemecahan masalah merupakan salah satu kemampuan yang dituntut dari tujuan kurikuler mata pelajaran IPS. Namun apa yang menjadi harapan dan tujuan dari mata pelajaran IPS tidak sepenuhnya sesuai dengan kondisi real di lapangan. Salah satu permasalahan yang sering terjadi adalah sebagian besar guru mengajarkan IPS sering memfokuskan pada pengembangan kemampuan tingkat rendah yang sifatnya hafalan dan pemahaman konsep saja, sedangkan kemampuan berpikir analisis dan kreatif sering terabaikan. Sementara itu pada praktik pelaksanaan pembelajaran IPS yang sering dijumpai guru cenderung menggunakan strategi mengajar konvensional seperti ceramah dan Tanya jawab saja.

Rendahnya kualitas proses pembelajaran IPS yang diselenggarakan oleh guru di kelas berimplikasi pada rendahnya hasil belajar yang diperoleh siswa. Berdasarkan hasil mid semester mata pelajaran IPS kelas V SDN 018 Langgini Bangkinang Kota, ditemukan hasil sebaga iberikut:
Tabel 1.1

Daftar Nilai Mid Semester kelas V SDN 018 Bangkinang Kota

\begin{tabular}{|l|l|c|}
\hline No & \multicolumn{1}{|c|}{ Nama } & Nilai \\
\hline 1 & AM & 50 \\
\hline 2 & ANI & 51 \\
\hline 3 & AFP & 71 \\
\hline 4 & AF & 80 \\
\hline 5 & ANP & 60 \\
\hline 6 & BM & 53 \\
\hline 7 & DN & 51 \\
\hline 8 & DF & 71 \\
\hline 9 & ED & 60 \\
\hline 10 & FR & 51 \\
\hline 11 & FP & 67 \\
\hline 12 & GSB & 71 \\
\hline 13 & HDP & 69 \\
\hline 14 & LP & 69 \\
\hline 15 & MS & 60 \\
\hline 16 & RI & 51 \\
\hline 17 & RRA & 80 \\
\hline & & \\
\hline
\end{tabular}

Jika kondisi demikian terus berlangsung, maka tujuan mata pelajaran IPS seperti yang diharapkan akan sulit tercapai. Oleh karena itu, sebagai guru yang professional hendaknya dapat dapat mengatasi masalah ini dengan menerapkan berbagai cara melalui pendekatan dan cara belajar yang mampu mencerminkan nilai-nilai sosial seperti kerjasama, tanggung jawab, semangat dan saling membantu. Dimana diantara siswa saling berinteraksi, berkomunikasi dan berbagi dalam memahami dan mempelajari materi pelajaran yang diberikan. Adapun alternatif yang dapat dipilih guru salah satunya adalah dengan penerapan metode Mind Mapping.

Adapun tujuan yang akan dicapai dalam penelitian ini adalah:

1. MenyusunRencanaPelaksanaanPembelajaran (RPP) dengan model mind mappinguntukmeningkatkankemampuanberpik irkreatifsiswapadamatapelajaran IPS di kelas V SDN Langgini.

2. Mengimplementasi langkah-langkah pembelajaran dengan penerapan model mind mapping untuk meningkatkan kemampuan berpikir kreatif siswa pada mata pelajaran IPS di kelas V SDN Langgini.

Belajar merupakan kegiatan paling pokok dalam proses belajar mengajarmanusia. Terutama dalam pencapaian tujuan institusional suatu lembaga pendidikan atau sekolah. Hal ini menunjukkan bahwa berhasil tidaknya suatu 
pencapaian tujuan pendidikan tergantung kepada bagaimana proses belajar mengajar yang dialami oleh individu. Menurut Nasution (1982:39), "belajar dianggap merupakan perubahan tingkah laku sebagai akibat dari

Pembelajaran mengandung makna adanya kegiatan mengajar dan belajar, di mana pihak yang mengajar adalah guru dan yang belajar adalah siswa yang berorientasi pada kegiatan mengajarkan materi yang berorientasi pada pengembangan pengetahuan, sikap, dan keterampilan siswa sebagai sasaran pembelajaran. Dalam proses pembelajaranakanmencakupberbagaikomponenlai nnya, seperti media, kurikulum, dan fasilitas pembelajaran. Arikunto (1993: 12) mengemukakan "pembelajaran adalah suatu kegiatan yang mengandung terjadinya proses penguasaan pengetahuan, keterampilan dan sikap oleh subjek yang sedang belajar". Lebih lanjut Arikunto (1993: 4) mengemukakan bahwa "pembelajaran adalah bantuan pendidikan kepada anak didik agar mencapai kedewasaan di bidang pengetahuan, keterampilan dan sikap".

IPS merupakan suatu program pendidikan dan bukan sub-disiplin ilmu tersendiri,sehingga tidakn akan ditemukan baik dalam nomenklatur filsafat ilmu, disiplin ilmu-ilmu sosial (social science), maupun ilmu pendidikan (Sumantri, 2001:89). Sosial Science Education Council (SSEC) dan National Council for Social Studies (NCSS), menyebut IPS sebagai "Social Science Education" dan "Social Studies". Dengan kata lain, IPS mengikuti cara pandang yang bersifat terpadu dari sejumlah mata pelajaran seperti : geografi, ekonomi, ilmu politik, ilmu hukum, sejarah, antropologi, psikologi, sosiologi, dan sebagainya.

Mind Mapping, merupakan salah satu model yang dapat diterapkan pada sekolah dasar. Mind Mapping itu sendiri disesuaikan dengan salah satu karakteristik anak sekolah dasar yang lebih senang bermain dan bergembira. Teknik mencatat mind map, membuat siswa harus mencatat atau meringkas menggunakan kata kunci dan gambar. Perpaduan inilah yang membentuk sebuah asosiasi di kepala siswa, sehingga ketika siswa melihat gambar atau kata kunci tersebut maka siswa akan dengan mudah mengingat materi yang berkaitan dengan gambar tersebut.

Buzan(2009) menyatakan bahwa: Mind Map adalah alternatif pemikiran kenseluruha otak terhadap pemikiran linear. Mind Map menggapai ke segala arah dan menangkap berbagai pikiran dari segala sudut. Mind Map adalah cara termudah untuk menempatkan informasi kedalam otak dan mengambil informasi keluar dari otak, mind map adalah cara mencatat yang kreatif,efektif, dan secara harfiah akan memetakan pikiran-pikiran kita, mind map juga sangat sederhana.

Mind Mapping merupakan teknik penyusunan catatan demi membantu siswa menggunakan seluruh potensi otak agar optimum. Caranya, menggabungkan kerja otak bagian kiri dan kanan."Berdasarkan penelitian di luar negeri, rata-rata anak mengingat 70-90\% dari seluruh materi anak saat selesai membuatr sendiri mind map-nya" (Edward, 2009:64).

Suatu strategi pembelajaran mempunyai keunggulan dan kekurangan. Demikian pula dengan metode Mind Mapping mempunyai beberapa keunggulan menurut Hernacki (Deporter, 2010) di antaranya :

1. Fleksibel: Di dalamnya jika seorang pembicara tiba-tiba teringat untuk menjelaskan suatu hal tentang pemikiran, Anda dapat dengan mudah menambahkannya di tempat yang sesuai dalam Peta Pikiran Anda tanpa harus kebingungan.

2. Dapat memusatkan pikiran : Anda tidak perlu berfikir untuk menangkap setiap kata yang dibicarakan.Sebaliknya, Anda dapat berkonsentrasi pada gagasannya.

3. Meningkatkan pemahaman :Ketika membaca suatu tulisan atau laporan tekhnik, Peta Pkiran akan meningkatkan pemahaman dan memberikan catatan tinjauan ulang yang sangat berarti nantinya.

4. Menyenangkan : Imajinasi dan kreativitas Anda tidak terbatas dan hal itu menjadikan pembuatan dan peninjauan ulang catatan lebih menyenangkan

Selain keunggulan tersebut pembelajaran kooperatif tipe mind mapping juga mempunyai kelemahan, di antaranya adalah dalam penerapannya memerlukan waktu yang cukup lama dan kemungkinan menimbulkan rasa jenuh bagi siswa yang kurang menyukai gambar.

Berdasarkan uraian diatas, dapat disimpulkan bahwa metode Mind Mapping lebih menekankan kepada alternatif pemikiran dari pusat pemikiran dan menyeluruh guna menggapai kesegala arah dan menangkap berbagai pikiran dari segala sudut sehingga dengan metode tersebut kemampuan berpikir kreatif siswa akan 
4 | Penerapan metode mind mapping untuk meningkatkan kemampuan berpikir kreatif siswa sekolah dasarRizki Ananda

berkembang karena siswa dengan sendirinya membuat pola pemikirannya sendiri.

Berpikir kreatif adalah sebuah kebiasaan dari pemikiran yang dilatih dengan memperhatikan intuisi, menghidupkan imajinasi, mengungkapkan kemungkinan-kemungkinan baru, membuka sudut pandang yang menakjubkan, dan membangkitkan ide-ide yang tidak terduga.

Sedangkan berpikir kreatif menurut Sukmadinata (2004) melibatkan kemampuan sebagai berikut : “1) mengajukan pertanyaan ;2) menimbang-nimbang informasi dan pemikiran baru dengan sikap terbuka ; 3) mencari hubungan terutama diantaranya yang tidak sama ; 4) melihat hubungan antara satu hal dengan yang lain ; 5) menerapkan pikirannya dalam setiap situasi untuk menghasilkan hal yang baru yang berbeda ; 6) memperhatikan intuisi”.

Jadi, berpikir kreatif adalah proses berpikir untuk menemukan hubungan-hubungan baru antara berbagai hal, menerima, mengingat, memberi analisa kritik dan mempergunakan hasilnya dalam pemecahan problem. Berpikir kreatif, yang membutuhkan ketekunan, disiplin diri, dan perhatian penuh, meliputi aktifitas mental seperti :

1. Mengajukan pertanyaan

2. Mempertimbangkan informasi baru dan ide yang tidak lazim dengan pikiran terbuka

3. Membangun keterkaitan, khususnya diantarahal-hal yang berbeda

4. Menghubungkan berbagai hal dengan bebas

5. Menerapkan imajinasi pada setiap situasi untuk menghasilkan hal baru dan berbeda

6. Mendengarkan intuisi

Karena berpikir kreatif melibatkan rasa ingin tahu dan bertanya, mendorong siswa untuk berpikir untuk meneliti masalah-masalah yang telah dipilih untuk didiskusikan berkaitan dengan materi yang dibahas. Dengan kemampuan berpikir kratif, siswa diharapkan mampu mengembangkan diri merakan dalam membuat keputusan dari berbagai sudut pandang untuk menyelesaikan masalah, karena berpikir kreatif adalah sebuah kunci dalam mengembangkan diri, maka setiap siswa diharapkan memiliki tingkat berpikir kreatif yang baik. Kebutuhan untuk berpikir kreatif itu tidak terbatas pada masalah-masalah rumit sebagaimana yang diyakini oleh sebagian kalangan, tetapi juga merupakan kebutuhan primer dalam kehidupan sehari-hari.

\section{METODE PENELITIAN}

Dalam penelitian ini, metode yang digunakan adalah metode penelitian tindakan kelas (PTK). Berikut ini adalah berbagai pengertian PTK (penelitian tindakan kelas) menurut para ahli dalam Kunandar (2011: 43):

1. Menurut Kemmis dan Taggart: Penelitian tindakan adalah suatu bentuk self-inquiry kolektif yang dilakukan oleh para partisipan didalam situasi sosial untuk meningkatkan rasionalitas dan keadilan dari praktik pendidikan dan praktik sosial mereka, serta mempertinggi pemahaman mereka terhadap praktik dan situasi dimana praktik itu dilaksanakan.

2. Kurt Lewin: penelitian tindakan adalah suatu rangkaian langkah yang terdiri atas empat tahap, yakni perencanaan, tindakan, pengamatan, dan refleksi.

3. Ebbut: penelitian tindakan adalah kajian sistematik dari upaya perbaikan pelaksanaan praktik pendidikan oleh sekelompok guru dengan melakukan tindakan-tindakan dalam pembelajaran, berdasarkan refleksi mereka mengenai hasil dari tindakan tersebut.

4. David Hopkins: PTK adalah sebuah bentuk kegiatan refleksi dari yang dilakukan oleh para pelaku pendidikan dalam suatu situasi kependidikan untuk memperbaiki rasionalitas dan keadilan tentang: (a) praktik-praktik kependidikan mereka, (b) pemahaman mereka tentang praktik-praktik tersebut, (c) situasi dimana praktik-praktik tersebut dilaksanakan.

Berdasarkan pengertian di atas penelitian tindakan kelas dapat didefinisikan sebagai suatu penelitian tindakan (action research) yang dilakukan oleh guru yang sekaligus sebagai peneliti di kelasnya atau bersama-sama dengan orang lain (kolaborasi) dengan jalan merancang, melaksanakan, dan merefleksikan tindakan secara kolaboratif dan partisipatif yang bertujuan untuk memperbaiki atau meningkatkan mutu proses pembelajaran di kelasnya melalui suatu tindakan tertentu dalam suatu siklus.

Mengingat dalam suatu penelitian tindakan kelas peneliti perlu dibantu oleh pendamping sebagai rekan diskusi bagi peneliti, maka dalam hal ini peneliti meminta bantuan guru kelas sebagai pengamat dalam penelitian, mulai dari perencanaan tindakan, pelaksanaan tindakan, observasi, refleksi, dan revisi selama peneliti melakukan penelitian di SDN 018 Langgini Bangkinang Kota. Penelitian tindakan kelas ini 
dilaksanakan melalui tahap-tahap yang umumnya dilaksanakan dalam suatu penelitian tindakan kelas. Tahap-tahap tersebut biasa disebut dengan siklus, dimana setiap siklusnya meliputi perencanaan, pelaksanaan tindakan, observasi, evaluasi, dan refleksi.

Kegiatan penelitian dilaksanakan berdasarkan perencanaan tindakan yang telah ditetapkan, yaitu melaksanakan pembelajaran sesuai rencana pembelajaran yang telah dibuat. Fokus tindakan adalah penggunaan metode Mind Mapping yang dioptimalkan untuk meningkatkan kemampuan berpikir kreatif siswa. Pada tahap pelaksanaan tindakan ini, proses pembelajaran dilaksanakan dengan menjalankan skenario pembelajaran yang telah dirancang dan terdapat dalam RPP.

Disaat tahapan pelaksanaan tindakan sedang berlangsung, pada waktu yang sama peneliti juga melaksanakan tahapan observasi. Pada tahap observasi ini, peneliti dibantu oleh pengamat penelitian (observer) mengumpulkan data untuk mendapatkan informasi terkait dengan proses pembelajaran menceritakan tokoh-tokoh sejarah pada masa Hindu-Budha dan Islam dengan menggunakan metode Mind Mapping. Hal ini dimaksudkan agar informasi yang ditemukan dapat lebih diorganisir pada lembar observasi untuk memperoleh kesimpulan dari proses pembelajaran menceritakan tokoh-tokoh sejarah pada masa Hindu-Budha dan Islam dengan menggunakan metode Mind Mapping. Hasil observasi proses pembelajaran inilah yang akan digunakan untuk analisis dan refleksi untuk menentukan langkah yang selanjutnya dalam penelitian tindakan kelas ini. Selain mengamati proses pembelajaran dengan menggunakan metode Mind Mapping, observer juga mengamati kemampuan berpikir kreatif siswa yang ada pada lembar observasi kemampuan berpikir kreatif pada pembelajaran, dan lembar observasi nilai Pendidikan Budaya Dan Karakter Bangsa (PBKB) untuk mengetahui peningkatan kualitas tingkah laku siswa. Pada tahap pelaksanaan tindakan ini, peneliti juga memberikan tes ketercapaian indikator kepada siswa, tes ini untuk mengetahui peningkatan pemahaman materi siswa berdasarkan aspek kognitif.

\section{HASIL DAN PEMBAHASAN PENELITIAN}

Berdasarkan tindakan yang telah dilaksanakan pada siklus I dan II pada pembelajaran IPS dengan menggunakan metode
Mind Mapping untuk meningkatkan kemampuan berpikir kreatif siswa di kelas $\mathrm{V}$ yaitu dijelaskan sebagai berikut:

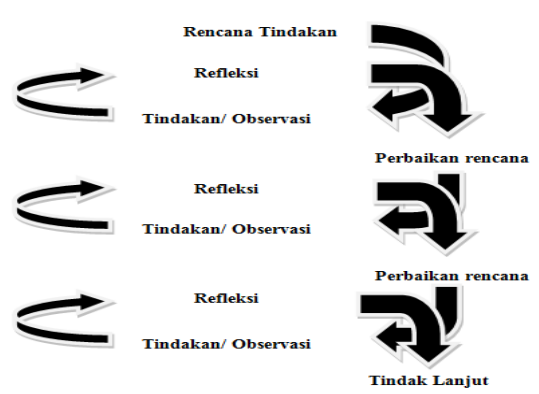

Dalam penelitian tindakan kelas ini, kualitas RPP yang dibuat diukur dengan menggunakan rubrik penilaian RPP. Setiap butir rencana kegiatan yang tertuang dari RPP dinilaai oleh pengamat berupa komentar atau catatancatatan penting. Penilaian RPP dilihat dari 6 aspek yang sesuai dengan rubrik penilaian RPP, yang terdiri dari: a) tujuan; b) langkah pembelajaran; c) materi pokok; d) sumber, media dan alat; e) penilaian; f) alokasi waktu.

Setelah menganalisis kualitas RPP yang dibandingkan dengan rubrik penilaian RPP. Pengamat menyatakan bahwa kualitas RPP siklus I dari segi perencanaan sudah cukup baik, menurutnya RPP yang dibuat peneliti memenuhi semua komponen dan telah sesui dengan rubrik penilaian RPP, namun dari segi pelaksanaannya terdapat beberapa kekurangan.

Kualitas RPP siklus II baik dari segi perencanaan maupun pelaksanaan telah menunjukan peningkatan dibandingkan dengan kualitas RPP siklus I, menurut pengamat kualitas RPP siklus II sudah sangat baik. Sehingga bila dibandingkan dengan indikator keberhasilan dalam penelitian ini, maka dapat dikatakan bahwa kualitas RPP yang disusun telah berhasil (berkualitas baik).

Berdasarkan hasil ketercapaian pada Rencana Pelaksanaan Pembelajaran (RPP) diatas, maka dapat ditarik kesimpulan bahwa pelaksanaan RPP telah memenuhi kriteria yang SANGAT BAIK didapat dalam Rencana Pelaksanaan Pembelajaran (RPP) pada siklus II, hal ini dapat dikaitkan dengan komponen penyususnan Rencana Pelaksanaan Pembelajaran (RPP) dalam teori di BAB II.

Pelaksanaan pembelajaran merupakan implementasi dari Rencana Pelaksanaan Pembelajaran (RPP). Pelaksanaan pembelajaran meliputi kegiatan pendahuluan,kegiatan inti dan 
6 | Penerapan metode mind mapping untuk meningkatkan kemampuan berpikir kreatif siswa sekolah dasarRizki Ananda

kegiatan pentup menurut Sanjaya (2009:79) "Pelaksanaan tindakan adalah perlakuan yang dilaksanakan guru berdasarkan perencanaan yang telah disusun ". Pada tahap ini serangkaian rancangan, strategi, skenario pembelajaran yang akan diterapkan. Implementasi pembelajaran yang dilakukan peneliti dari siklus I sampai II menggunakan metode Mind Mapping .

Implementasi pembelajaran tokoh-tokoh sejarah pada masa Hindu-Budha dan Islam di Indonesia dengan mnggunakan metode Mind Mapping, berikut ini akan dibahas satu persatu sari setiap siklusnya.

Berdasarkan analisis data tentang pengamatan terhadap proses ketercapaian pelaksanaan RPP siklus I, maka menurut pengamat dari 21 komponen yang diamati, pelaksanaannya muncul sebanyak 17 komponen saja (81\%). Dengan demikian bila dikategorikan, pelaksanaan RPP dalam pembelajaran siklus I masuk dalam kategori SANGAT BAIK. Ini bererti bahwa pelaksanaan RPP pada pembelajaran siklus I belum tercapai secara keseluruhan.

Hasil analisis data tentang pengamatan terhadap proses ketercapaian pelaksanaan RPP, maka menurut pengamat bahwa seluruh komponen pada lembar observasi proses pembelajaran yang berjumlah 21 komponen menunjukan peningkatan, setiap komponen muncul dan terlaksana dengan baik, guru mengikuti sarana dan kritik dari pengamat untuk melakukan perbaikanperbaikan.Dengan demikian, ketercapaian pelaksanaan pembelajaran siklus II dinyatakan berhasil secara keseluruhan dan mempunyai kategori SANGAT BAIK dengan nilai persentase mencapai $100 \%$.

Berdasarkan hasil ketercapaian pelaksanaan Rencana Pelaksanaan Pembelajaran (RPP) diatas, maka dapat ditarik kesimpulan bahwa pelaksanaan Rencana Pelaksanaan Pembelajaran (RPP) telah memenuhi kriteria yang SANGAT BAIK didapat dalam pelaksanaan Rencana Pelaksanaan Pembelajaran (RPP) pada siklus II, hal ini dapat dikaitkan dengan komponen penyususnan RPP dalam teori di BAB II.

Berdasarkan analisis data hasil pengamatan terhadap kemampuan berpikir kreatif siswa kelas V di SDN 018 Langgini mengalami peningkatan secara signifikan pada siklus II, yang awalnya pada pelaksanaan tindakan siklus I ada beberapa siswa dalam kelompok belum menunjukan kemampuan berpikir kreatif mereka ketika diskusi kelompok. Namun pada siklus II, seluruh siswa dalam kelompok telah menunjukan kemampuan berpikir kreatif mereka pada saat diskusi kelompok.

Gambaran nyata mengenai peningkatan kemampuan berpikir kreatif siswa pada proses pelaksanaan pembelajaran dari siklus I sampai II dapat dilihat pada grafik di bawah ini.

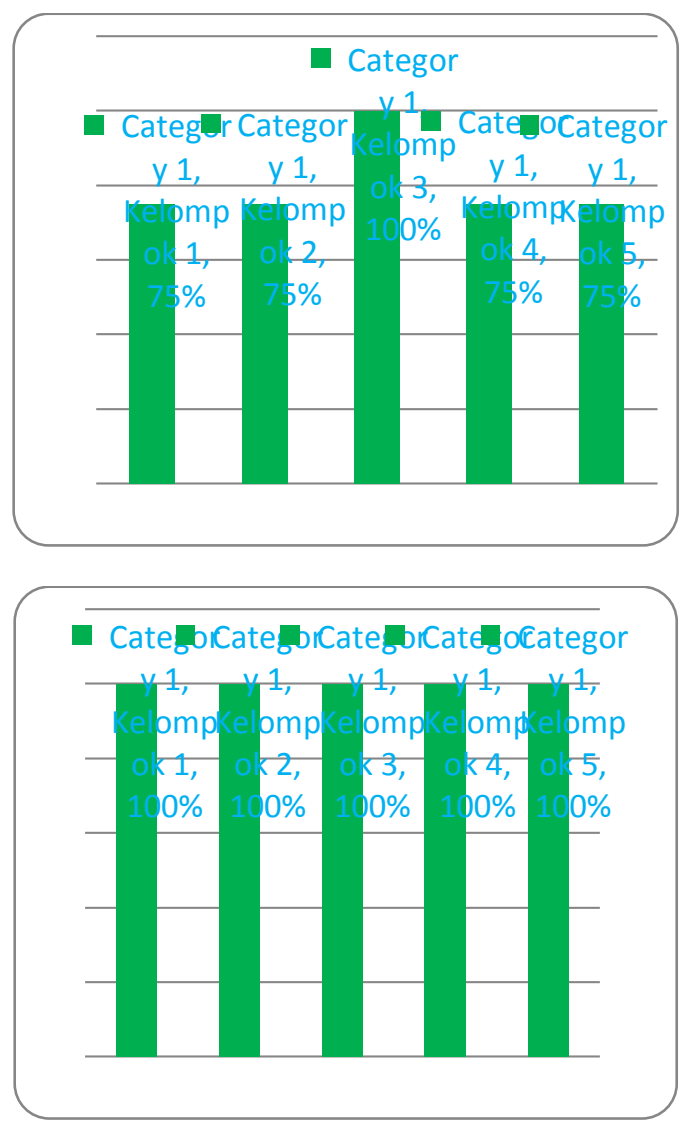

\section{Gambar 1.3}

Diagram peningkatan kualitas kemampuan berpikir kreatif siswa Siklus I dan Siklus II

Angket respon digunakan untuk mengetahui tanggapan siswa dalam pembelajaran IPS materi tikoh-tokoh sejarah pada masa HinduBudha dan Islam di Indonesia menggunakan metode Mind Mapping. Respon siswa tersebut dapat diukur dengan butir-butir pernyataan yang harus direspon siswa.

Berdasarkan hasil analisis data angket tespon siswa, diketahui bahwa respon siswa terhadap pembelajaran IPS materi tikoh-tokoh sejarah pada masa Hindu-Budha dan Islam di Indonesia menggunakan metode Mind Mapping .

Berdasarkan penghitungan terhadap seluruh item angket, maka diketahui:

a. item angket nomor 1 mendapat response banyak $80 \%$ (hamper seluruhnya) 
7 | Penerapan metode mind mapping untuk meningkatkan kemampuan berpikir kreatif siswa sekolah dasarRizki Ananda

b. item angket nomor 2 mendapat respon sebanyak $100 \%$ (seluruhnya)

c. item angket nomor 3 mendapat respon sebanyak $85 \%$ (hamper seluruhnya)

d. item angket nomor 4 mendapat respon sebanyak 90\% (hamper seluruhnya)

e. item angket nomor 5 mendapat respon sebanyak 90\% (hamper seluruhnya)

f. item angket nomor 6 mendapat respon sebanyak $100 \%$ (seluruhnya)

g. item angket nomor 7 mendapat respon sebanyak $100 \%$ (seluruhnya)

h. item angket nomor 8 mendapat respon sebanyak $100 \%$ (seluruhnya)

i. tem angket nomor 9 mendapat respon sebanyak $100 \%$ (seluruhnya)

item angket nomor 10 mendapat respon sebanyak $100 \%$ (seluruhnya).

\section{KESIMPULAN}

Berdasarkan hasil penelitian dapat disimpulkan sebagai berikut:

1. Peningkatkan kemampuan berpikir kreatif siswa pada pembelajaran IPS kelas $\mathrm{V}$ pada materi " tokoh-tokoh sejarah pada massa Hindu Budha dan Islam di indonesia" di SDN 018 Langgini Bangkinang Kota. Hal itu dapat dilihat dari kualitas RPP pada siklus I dan siklus II dimana pada siklus I menunjukkan nilai dengan kategor Baik, siklus II kualitas menunjukkan peningkatan nilai yang signifikan menjadi Sangat Baik.

2. Pelaksanaan Pembelajaran IPS dengan menggunakan metode Mind Mapping mampu dan dapat meningkatkan kemampuan berpikir kreatif, karena dengan metode Mind Mapping lebih menyenangkan dan siswa aktif dalam proses pembelajaran dan siswa mampu menambah pengetahuan dan memunculkan ideide dalam memecahkan masalah yang muncul dalam proses pembelajaran. Hal initerbuktidenganmeningkatnyanilaipersentase proses pembelajaran dari siklus I kesiklus II secarasignifikan.

3. Indikator ketercapaian siswa dengan penggunaan metode mind mapping padap embelajaran IPS pada materi "tokoh-tokoh sejarah pada masa Hindu-Budhadan Islam di Indonesia di kelas V SDN Langgini" dapat meningkat. Hal ini terbukti dengan adanya peningkatan pada setiap proses pelaksanaan tindakan pembelajaran, kesimpulan tersebut adalah sebagai berikut:

a. Nilai Pretest Siswa : Adanya peningkatan signifikan dari nilai pretes, dengan demikian metode Mind Mapping dapat meningkatkan nilai pretes.

b. Nilai Postest Siswa

a) adanya peningkatan yang signifikan dari nilai postes, dengan demikian metode Mind Mapping dapat meningkatkan nilai postes.

b) nilai rata-rata siswa 56 setelah menggunakan metode Mind Mapping meningkat menjadi lebih besar dari KKM.

c. Kemampuan Berpikir Kreatif Siswa : Pelaksanaan metode Mind Mapping dapat meningkatkan kemampuan berpikir kreatif siswa menjadi lebih baik.

d. Nilai PBKB : Nilai PBKB siswa setelah menggunakan metode Mind Mapping menjadi lebih baik.

e. Respon siswa terhadap pelaksanaan pembelajaran IPS materi tokoh-tokoh sejarah pada masa Hindu-Budha dan Islam di Indonesia dengan menggunakan metodeMind Mapping yang di ikutinya dirasakan menarik dan cukup baik.

Berdasarkan deskripsi diatas,maka dapat ditarik kesimpulan bahwa penggunaan metodeMind Mapping mampu dan dapat meningkatkan kemampuan berpikir kreatif siswa pada materi tokoh-tokoh sejarah pada massa Hindu Budha dan Islam di Indonesia di kelas V SDN 018 Langgini.

\section{DAFTAR PUSTAKA}

Arikunto, Suharsimi. (1993). Prosedur Penelitian: Suatu Pendekatan Praktek. Jakarta: Rineka Cipta.

BSNP. (2006). Isi, Tujuan, dan Ruang Lingkup Kurikulum Tingkat Satuan Pendidikan (KTSP). Jakarta: Depdiknas.

Buzan, Tony. (2005). Buku Pintar Mind Map. Jakarta: PT. Gramedia Pustaka Utama.

Deporter, Bobby. (2010). Quantum Teaching (Mempraktikkan Quantum Learning di Ruang Kelas. Bandung: Kaifa. 
8 | Penerapan metode mind mapping untuk meningkatkan kemampuan berpikir kreatif siswa sekolah dasarRizki Ananda

Kunandar. (2011). Langkah Mudah Penelitian Tindakan Kelas Sebagai Pengembangan Profesi Guru. Jakarta: Rajawali Pres.

Nasution, S. (1983). Sosiologi Pendidikan. Bandung: Jemmars.

Sanjaya, Wina. (2009). Kajian Kurikulum dan Pembelajaran di SD. Bandung: Universitas Pendidikan Indonesia.

Sapriya. (2012). Pendidikan IPS: Konsep dan Pembelajaran. Bandung: PT. Remaja Rosdakarya.

Slavin, Robert E. (2005). Cooperative Learning Teori, Riset, dan praktik. Bandung: Nusa Media.
Solihatin, Etin. (2007). Cooperative Learning:Analisis Model Pembelajaran IPS. Jakarta: Bumi Aksara

Sukmadinata, Nana Syaodih. (2004). Kurikulum \& Pembelajaran Kompetensi. Bandung: PT. Remaja Rosdakarya.

Sumantri, M. Nu'man. (2001). Menggagas Pembaharuan Pendidikan IPS. Bandung: PT. Remaja Rosda Karya.

Suyadi. (2010). Panduan Penelitian Tindakan Kelas. Yogyakarta : DIVA Press.

Wiriaatmadja, Rochiati. (2008). Metode Penelitian Tindakan Kelas untuk Meningkatkan Kinerja Guru dan Dosen. Bandung: PT. Remaja Rosdakarya 